\section{Competitive Effect of In-row Diploid Watermelon Pollenizers on Triploid Watermelon Yield}

\author{
Joshua H. Freeman ${ }^{1}$ and Stephen M. Olson ${ }^{2}$ \\ Department of Horticultural Sciences, University of Florida, North Florida \\ Research and Education Center, 155 Research Road, Quincy, FL 32351
}

William M. Stall

Department of Horticultural Sciences, University of Florida, Box 110690 Fifield Hall, Gainesville, FL 32611

Additional index words. cucurbitaceae, Citrullus lanatus, seeded, seedless

\begin{abstract}
Successful fruit set in triploid watermelons [Citrullus lanatus (Thunb.) Matsum. \& Nakai] requires a diploid watermelon cultivar, or pollenizer, to be planted nearby as a pollen source. Pollenizer cultivars have been developed to be planted in-row with triploid plants without spacing change, which decreases area per plant. These cultivars have different growth habits, from highly reduced foliage to standard foliage, and it is uncertain how pollenizer growth habit may affect triploid plant growth and yield. Two diploid watermelon pollenizers, 'Mickylee' and 'SP-1', with markedly different growth habits were planted at five in-row spacings from triploid plants to determine the effect of plant competition on triploid watermelon yield. All treatments used a 1:1 pollenizer to triploid ratio to measure the direct effect of pollenizer growth on associated triploid yields. Experiments were conducted at two locations during Spring 2006 (Quincy and Citra, FL) and one during Fall 2006 (Quincy). Triploid plants paired with 'Mickylee' yielded 11.4\% (Citra) and $22.4 \%$ (Quincy) less weight in the spring and $8.5 \%$ less in the fall than plants paired with 'SP-1' and also produced fewer fruits per plant. However, the results from the fall trial were not significant. Pollenizer to triploid spacing had a linear effect on yield per plant and fruits per plant, and there was no interaction between pollenizer cultivar and spacing. The use of 'Mickylee' as a pollenizer may be an attractive option because of lower seed costs compared with other pollenizers, but these results indicated lower triploid watermelon yields from plants paired with 'Mickylee', which is most likely a result of increased plant competition.
\end{abstract}

Over the last decade, the popularity of triploid watermelons has increased. In 2006, triploid watermelons accounted for $78 \%$ of the watermelons sold in the United States and averaged 4.5 to 11 cents more per kilogram than seeded watermelons (USDA, 2006). Unlike diploid plants, triploid watermelon plants do not produce sufficient viable pollen to pollenize themselves (Maynard, 1992; Maynard and Elmstrom, 1992). To achieve optimal triploid watermelon yields, $20 \%$ to $33 \%$ of the plants in the field should be diploid, because a diploid cultivar can provide pollen for the pollination of the triploids (Fiacchino and Walters, 2003; NeSmith and Duval, 2001). Traditionally, dedicated rows were set aside for the diploid cultivars. Multiple pollenizer cultivars with diverse growth habits have now been developed to be interplanted among triploid plants. By eliminating

Received for publication 19 Apr. 2007. Accepted for publication 25 May 2007.

${ }^{1}$ Current address: Department of Horticulture, Virginia Polytechnic Institute and State University, Eastern Shore Agricultural Research and Extension Center, Painter, VA 23420.

${ }^{2}$ To whom reprint requests should be addressed; e-mailsmolson@ufl.edu. dedicated row space in the field for pollenizers, the number of triploid plants per hectare increases and per-hectare yield should also increase.

Many in-row pollenizer cultivars have varying degrees of reduced foliage, which is intended to cause less competitive impact on adjacent triploid plants. This is important because previous studies on watermelon competition with weed species have shown watermelon to be a poor competitor because it can withstand little plant competition without a reduction in yield (Buker et al., 2003; Monks and Schultheis, 1998; Terry et al., 1997). However, in-row pollenizers have two to three times greater seed/plant costs than standard hybrid diploid cultivars and 25 times greater than open-pollinated diploids. There has been interest in using openpollinated diploid cultivars in-row; however, most are not easily distinguishable from commonly grown triploid watermelons. One cultivar that is being evaluated by researchers for its potential use in-row is 'Mickylee', which produces a visually distinguishable gray watermelon.

One critical aspect of pollenizers is staminate flower production, and previous research has shown that 'Mickylee' produces similar numbers of male flowers as other in- row pollenizer cultivars (Freeman and Olson, 2007). The growth habit of 'Mickylee' is similar to that of standard cultivars and it is unclear whether this will have a negative competitive impact on closely associated triploid plants. Most in-row pollenizers are recommended to be planted at a 1:3 pollenizer to triploid ratio, which means pollenizer growth will directly impact two-thirds of the triploid plants per hectare. These are the triploid plants that are directly adjacent to the pollenizer plants.

Studies in watermelon that have investigated the effect of in-row spacing on yield have shown that yield and fruit per plant decrease with closer spacing (Brinen et al., 1979; Duthie et al., 1999a, 1999b; Goreta et al., 2005; Motsenbocker and Arancibia, 2002; NeSmith, 1993; Sanders et al., 1999). However, these studies are not in agreement as to whether decreased in-row spacing decreases average fruit weight. Similar studies on other cucurbits such as pumpkin (Cucurbita pepo L.) and muskmelon (Cucumis melo L.) have shown that decreased inrow spacing decreases average fruit weight (Kultur et al., 2001; Maynard and Scott, 1998; Reiners and Riggs, 1997, 1999). Studies investigating competition between several weed species and watermelon have shown decreased yield as a function of decreased fruit number and not decreased average fruit size (Buker et al., 2003; Monks and Schultheis, 1998).

Before 2005, little information was available on the use of these special in-row pollenizer cultivars (Boyhan et al., 2003; Maynard, 2001). Because this is a relatively new concept in the United States, it is unclear which pollenizers are more effective and how their growth habit will affect closely associated triploid plants. The objective of this study was to determine the effects of pollenizer growth habit and pollenizer to triploid spacings on triploid watermelon yield.

\section{Materials and Methods}

Three experiments were conducted, one at the North Florida Research and Education Center (NFREC) in Quincy, FL, and one at the Plant Science Research and Education Unit (PSREU) in Citra, FL, during Spring 2006. The third was at NFREC during Fall 2006. Soil type at NFREC was Norfolk loamy sand (fine-loamy, kaolinitic, thermic Typic Kandiudults) and at PSREU was Hague sand (loamy, siliceous, semiactive, hyperthermic Arenic Hapludalfs). At NFREC (spring and fall), all fertilizer was incorporated preplant at a rate of $183 \mathrm{~N}-24 \mathrm{P}-152 \mathrm{~K} \mathrm{~kg} \cdot \mathrm{ha}^{-1}$. At PSREU, two-thirds of the fertilizer was applied preplant and the remainder of the recommendation was fulfilled through weekly fertigation. Total fertilizer applied at PSREU was $168 \mathrm{~N}-48 \mathrm{P}-140 \mathrm{~K} \mathrm{~kg} \cdot \mathrm{ha}^{-1}$. Fertilization was based on soil test results and University of Florida recommendations (Olson et al., 2006). At both locations, irrigation was provided through drip tape $\left(1.89 \mathrm{~L} \cdot \mathrm{min}^{-1} / 30.48 \mathrm{~m}\right.$ at $68 \mathrm{kPa} ; 30.48-\mathrm{cm}$ emitter spacing), which 
was laid concurrently with black polyethylene mulch in the spring and white on black in the fall. Soil was fumigated at plastic laying with methyl bromide/chloropicrin (67:33) at broadcast rate of $448 \mathrm{~kg} \cdot \mathrm{ha}^{-1}$. Beds were spaced $2.43 \mathrm{~m}$ center to center. The experimental design was a randomized complete block with four replications and a factorial arrangement of two pollenizer cultivars and five inrow spacings. In-row spacings between one pollenizer plant and one triploid plant were $0.2,0.4,0.6,0.8$, and $1.0 \mathrm{~m}$. These spacings would be exactly half the in-row spacing from triploid to triploid. Plots consisted of six pairs (one pollenizer, one triploid) of plants with equal pollenizer to triploid spacings. Each pair of plants was spaced $1.0 \mathrm{~m}$ in-row from the next pair to reduce competition from adjacent pairs (Fig. 1). The experimental design was artificial compared with field production but was necessary to measure direct competition between pollenizer and triploid plants. On 21 Mar., 3 Apr., and 1 Aug., 4-week-old watermelon seedlings were transplanted. 'Sugarheart' triploid was

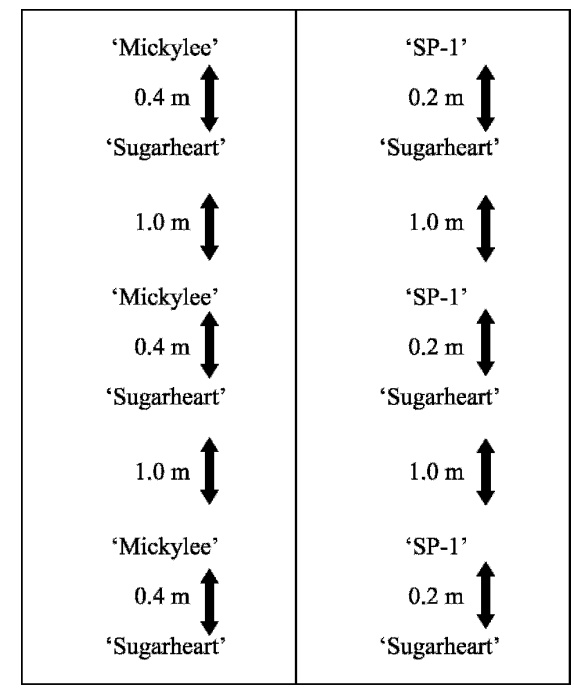

Columns represent individual rows. Numbers of plants represented are fewer than used in actual experiment.

Fig. 1. Example plot layout showing two pollenizers and two in-row spacings. used along with 'Mickylee' (standard vining habit) and 'SP-1' (reduced foliage, thin vines) as pollenizers. Harvests of spring trials were made on 8 and 19 June at PSREU and on 21 and 28 June and 7 July at NFREC. Fall harvests were on 11 and 25 Oct. Watermelons were harvested at maturity and on final harvest dates, all melons of marketable size were harvested. Insecticides and fungicides were applied as needed to maintain plant health (Olson et al., 2006). Groupings of honeybee (Apis mellifera L.) hives were placed in close proximity to all experiments. The GLM procedures of SAS (SAS Institute, Cary, NC) were used to analyze the effects of pollenizer cultivar on 'Sugarheart' watermelon yield and interactions between pollenizer cultivar and spacing. The GLM procedures were also used to analyze the polynomial effects of pollenizer to triploid spacing.

\section{Results}

Pollenizer cultivar and plant spacing had significant effects on triploid watermelon yield and fruit production per plant (fpp) at Citra and Quincy in the spring but not at Quincy in the fall. However, the significance of cultivar and plant spacing on fruit production at Citra were $P=0.0983$ and $P=$ 0.0633 , respectively. Plant spacing had significant linear effects on triploid watermelon yield and fpp at both locations in the spring (Table 1). No significant effects on average watermelon weight were observed in any of the experiments. Cultivar and plant spacing had no effect on triploid watermelon yield or yield components at Quincy in the fall. No significant interaction effects were observed between cultivar and plant spacing, so plant spacing results were pooled over cultivar and cultivar data were pooled over plant spacing. A significant interaction between location and pollenizer cultivar was detected in the spring; therefore, locations were presented separately.

Triploid watermelon yields from plants paired with 'Mickylee' at Citra and Quincy were 24.6 and $33.5 \mathrm{~kg} /$ plant, respectively. Yields from plants paired with 'SP-1' at Citra and Quincy were 27.7 and $43.3 \mathrm{~kg} /$ plant, respectively, which were significantly greater than yields from plants paired with 'Mickylee'. At Quincy, plants paired with 'Mickylee' produced $3.74 \mathrm{fpp}$, which was significantly lower than $4.85 \mathrm{fpp}$ produced by plants paired with 'SP-1' (Table. 1). At Citra, plants paired with 'Mickylee' produced $3.68 \mathrm{fpp}$, which was lower than 4.04 fpp produced by plants paired with 'SP-1'; however, this was only statistically significant at $P=0.10$.

Triploid watermelon yields and fpp increased linearly with increased spacing at both locations during the spring. Yields from plots with $0.2 \mathrm{~m}$ in-row spacings were 22.1 and $32.0 \mathrm{~kg} / \mathrm{plant}$ at Citra and Quincy, respectively. Yields from plots with $1.0 \mathrm{~m}$ in-row spacing were 30.8 and $47.8 \mathrm{~kg} /$ plant at Citra and Quincy, respectively.

\section{Discussion}

These results from the spring trials appear to indicate that the more vigorous growth habit of the pollenizer 'Mickylee' negatively impacted yield of the triploid cultivar 'Sugarheart' compared with 'SP-1', which has reduced foliage. Although results from the fall trials were not significant, the same trend in yield reduction resulting from pollenizer cultivar was observed.

Regardless of in-row spacing, triploid watermelon plants paired with 'Mickylee' yielded (kg/plant) $11.4 \%$ and $22.4 \%$ less weight than plants paired with 'SP-1' at Citra and Quincy, respectively. Yields from plants paired with 'Mickylee' in the fall were 8.5\% lower than those paired with 'SP-1'; however, this difference was not significant. At current pollenizer ratios recommended by seed producers, pollenizer competition would directly affect two-thirds of the triploid plants per hectare. These yield reductions can be expected at all in-row spacings because there was no interaction between cultivar and spacing. Extrapolations of yield to a per-hectare basis were not performed because it is unclear how many pollenizer plants would be necessary at these plant populations, which ranged from 10,089 plants/ ha at the closest spacings to 2017 plants/ha at

Table 1. Influence of two pollenizer cultivars and five pollenizer to triploid spacings on yield of the triploid watermelon Sugarheart at Citra and Quincy, FL, during 2006.

\begin{tabular}{|c|c|c|c|c|c|c|c|c|c|}
\hline \multirow[b]{3}{*}{ Treatment } & \multicolumn{9}{|c|}{ Location } \\
\hline & \multicolumn{3}{|c|}{ Citra Spring 2006} & \multicolumn{3}{|c|}{ Quincy Spring 2006} & \multicolumn{3}{|c|}{ Quincy Fall 2006} \\
\hline & $\begin{array}{c}\text { Fruit } \\
\text { (no./plant) }\end{array}$ & $\begin{array}{c}\text { Yield } \\
\text { (kg/plant) }\end{array}$ & $\begin{array}{l}\text { Avg. fruit } \\
\text { wt. (kg) }\end{array}$ & $\begin{array}{c}\text { Fruit } \\
\text { (no./plant) }\end{array}$ & $\begin{array}{c}\text { Yield } \\
\text { (kg/plant) }\end{array}$ & $\begin{array}{l}\text { Avg. fruit } \\
\text { wt. (kg) }\end{array}$ & $\begin{array}{c}\text { Fruits } \\
\text { (no./plant) }\end{array}$ & $\begin{array}{c}\text { Yield } \\
\text { (kg/plant) }\end{array}$ & $\begin{array}{c}\text { Avg. fruit } \\
\text { wt. }(\mathrm{kg})\end{array}$ \\
\hline \multicolumn{10}{|c|}{ Pollenizer cultivar } \\
\hline SP-1 & 4.04 & 27.7 & 6.8 & 4.85 & 43.4 & 8.8 & 3.04 & 19.0 & 6.2 \\
\hline Mickylee & 3.68 & 24.5 & 6.7 & 3.74 & 33.5 & 8.8 & 2.85 & 17.4 & 6.0 \\
\hline Significance & $*$ & $* *$ & NS & $* * *$ & $* * *$ & NS & NS & NS & NS \\
\hline \multicolumn{10}{|l|}{ Spacing $(\mathrm{m})^{\mathrm{z}}$} \\
\hline 0.2 & 3.33 & 22.1 & 6.5 & 3.57 & 32.0 & 8.9 & 2.98 & 18.2 & 6.0 \\
\hline 0.4 & 3.68 & 24.9 & 6.7 & 3.46 & 29.7 & 8.4 & 2.85 & 17.5 & 6.0 \\
\hline 0.6 & 3.92 & 26.3 & 6.7 & 4.52 & 40.4 & 8.8 & 2.86 & 18.4 & 6.4 \\
\hline 0.8 & 4.02 & 26.6 & 6.7 & 4.85 & 43.9 & 9.0 & 3.18 & 19.3 & 6.0 \\
\hline 1.0 & 4.35 & 30.8 & 7.1 & 5.28 & 47.8 & 9.0 & 2.86 & 17.6 & 6.1 \\
\hline Significance & $\mathrm{L} * * *$ & $\mathrm{~L} * * *$ & NS & L*** & $\mathrm{L}^{* * *}$ & NS & NS & NS & NS \\
\hline
\end{tabular}

${ }^{\mathrm{z}}$ Distance between one pollenizer and one triploid plant.

Ns, ${ }^{* * *}, * * *$ Nonsignificant or significant at $P \leq 0.10,0.05$, or 0.01 , respectively. For plant spacings, significant effects were linear (L). 
the widest. There was also no yield data from triploid plants that were not directly affected by pollenizer competition. In a field setting, this would be plants that were not directly adjacent to a pollenizer.

During the fall experiment at Quincy, a severe outbreak of gummy stem blight [Didymella bryoniae (Auersw.) Rehm] slowed plant growth and caused premature plant senescence near the end of the season. This reduced triploid watermelon yields, which most likely led to a lack of significant effects. Similar trends in pollenizer cultivar effect on fruits per plant and yield per plant were observed; however, the effects were not significant.

The trends in fruit yield and fruit number observed in this study were similar to other reports in watermelon in which increased plant population, and thus increased competition, changed yield through fruit number and not average fruit mass (Brinen et al., 1979; Duthie et al., 1999a, 1999b; NeSmith, 1993). Competition studies investigating weed species effect on watermelon yield have also shown increasing competition lowers watermelon yield as a function of fruit number and not fruit size (Buker et al., 2003; Monks and Schultheis, 1998).

These results are not in agreement with Freeman et al. (2007), who evaluated the performance of in-row pollenizers and found no difference in triploid watermelon yield between plots containing 'Mickylee' or 'SP1'. The reported experimental design was intended to compare pollenizer cultivars as a function of pollen provided by each cultivar and not its competitive effect. Freeman et al. (2007) collected yield data by plot, which does not provide insight into pollenizer to triploid competition because some plants were located directly beside pollenizers and some were not. It is unclear why a significant reduction in yield incited by 'Mickylee' in this study was not in agreement with the results reported by Freeman et al. (2007).

'Mickylee' is an attractive option as a pollenizer because of its low seed costs compared with that of other pollenizer cultivars. However, the results of this study indi- cated that triploid watermelon yields and fruits per plant were significantly decreased when 'Mickylee' was used as a pollenizer as compared with 'SP-1' regardless of in-row spacing.

\section{Literature Cited}

Boyhan, G.E., D.M. Granberry, W.T. Kelley, K.L. Lewis, W.T. Jennings, J.K. Phillips, and C.R. Hill. 2003. Watermelon and cantaloupe variety trials, pollenizer evaluation and watermelon production in Georgia. Univ. GA. Coop. Ext. Serv. Miscellaneous publication MP107. 17 May 2007. <http://pubs.caes.uga.edu/caespubs/ pubcd/MP107.htm>.

Brinen, G.H., S.J. Locascio, and G.W. Elmstrom. 1979. Plant and row spacing, mulch, and fertilizer rate effects on watermelon production. J. Amer. Soc. Hort. Sci. 104:725-726.

Buker, R.S., W.M. Stall, S.M. Olson, and D.G. Schilling. 2003. Season-long interference of yellow nutsedge (Cyperus esculentus) with direct-seeded and transplanted watermelon (Citrullus lanatus). Weed Tech. 17:751-754.

Duthie, J.A., B.W. Roberts, J.V. Edelson, and J.W. Shrefler. 1999a. Plant density-dependent variation in density, frequency, and size of watermelon fruits. Crop Sci. 39:412-417.

Duthie, J.A., J.W. Shrefler, B.W. Roberts, and J.V. Edelson. 1999b. Plant density-dependent variation in marketable yield, fruit biomass, and marketable fraction in watermelon. Crop Sci. 39:406-412.

Fiacchino, D.C. and S.A. Walters. 2003. Influence of diploid pollenizer frequencies on triploid watermelon quality and yields. HortTechnology 13:58-61.

Freeman, J.H., G.A. Miller, S.M. Olson, and W.M. Stall. 2007. Diploid watermelon pollenizer cultivars differ with respect to triploid watermelon yield. HortTechnology (in press).

Freeman, J.H. and S.M. Olson. 2007. Characteristics of watermelon pollenizer cultivars for use in triploid production. Int. J. Veg. Sci. (in press).

Goreta, S., S. Perica, G. Dumicic, L. Bucan, and K. Zanic. 2005. Growth and yield of watermelon on polyethylene mulch with different spacings and nitrogen rates. HortScience 40:366-369.

Kultur, F., H.C. Harrison, and J.E. Staub. 2001. Spacing and genotype affect fruit sugar concentration, yield, and fruit size of muskmelon. HortScience 36:274-278.
Maynard, D.N. 1992. Growing seedless watermelon. Univ. FL. Coop. Ext. Serv. Fact sheet HS687. 12 Dec. 2006. <http://edis.ifas.ufl.edu/ CV006>.

Maynard, D.N. 2001. Watermelons-Characteristics, production, and marketing. ASHS Press, Alexandria, VA.

Maynard, D.N. and G.W. Elmstrom. 1992. Triploid watermelon production practices and varieties. Acta Hort. 318:169-173.

Maynard, E.T. and W.D. Scott. 1998. Plant spacing affects yield of 'Superstar' muskmelon. HortScience 33:52-54.

Monks, D.W. and J.R. Schultheis. 1998. Critical weed free period for large crabgrass (Digitaria sanguinalis) in transplanted watermelon. Weed Sci. 46:530-532.

Motsenbocker, C.E. and R.A. Arancibia. 2002. In-row spacing influences triploid watermelon yield and crop value. HortTechnology 12:437440.

NeSmith, D.S. 1993. Plant spacing influences watermelon yield and yield components. HortScience 28:885-887.

NeSmith, S. and J. Duval. 2001. Fruit set of triploid watermelon as a function of distance from a diploid pollenizer. HortScience 36:60-61.

Olson, S.M., E.H. Simonne, W.M. Stall, P.D Roberts, S.E. Webb, T.G. Taylor, and S.A. Smith. 2006. Cucurbit production in Florida, p. 191-237. In: S.M. Olson and E.H. Simonne (eds.). Vegetable production handbook for Florida. Univ. Fla. Coop. Ext. Serv. and Vance Publishing, Lenexa, KS.

Reiners, S. and D.I.M. Riggs. 1997. Plant spacing and variety affect pumpkin yield and fruit size but supplemental nitrogen does not. HortScience 32:1037-1039.

Reiners, S. and D.I.M. Riggs. 1999. Plant population affects yield and fruit size of pumpkin. HortScience 34:1076-1078.

Sanders, D.C., J.D. Cure, and J.R. Schultheis. 1999. Yield response of watermelon to planting density, planting pattern, and polyethylene mulch. HortScience 34:1221-1223.

Terry, E.R., W.M. Stall, D.G. Shilling, T.A. Bewick, and S.R. Kostewicz. 1997. Smooth amaranth interference with watermelon and muskmelon production. HortScience 32:589606.

U.S. Department of Agriculture (USDA). 2006 National watermelon report. U.S. Dept. Agr. Agricultural Marketing Service, Thomasville, GA. 15 Dec. 2006. <http://www.ams.usda.gov>. 